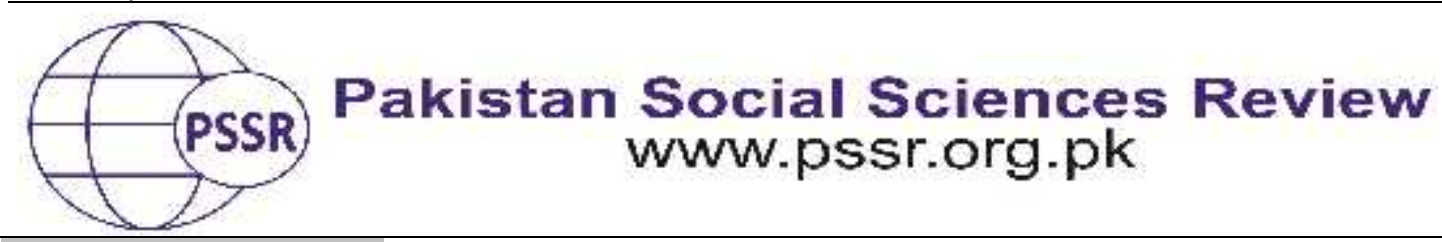

RESEARCH PAPER

\title{
Planning Teaching and Learning: Examining Potential Benefits as Perceived by School Teachers
}

\author{
Dr. Bashir Hussain ${ }^{1}$ Dr. Asia Zulfqar*2 Dr. Muhammad Arshad Javaid ${ }^{3}$
}

1. Associate Professor, Department of Education, Bahauddin Zakariya University, Multan, Punjab, Pakistan

2. Assistant Professor, Department of Education, Bahauddin Zakariya University, Multan, Punjab, Pakistan

3. Associate Professor, Department of Education, University of Education Lahore DG khan Campus, Punjab, Pakistan

\begin{tabular}{|c|c|}
\hline PAPER INFO & ABSTRACT \\
\hline $\begin{array}{l}\text { Received: } \\
\text { March 18, } 2021 \\
\text { Accepted: } \\
\text { June 20, } 2021 \\
\text { Online: } \\
\text { June 25, } 2021\end{array}$ & $\begin{array}{l}\text { Planning of teaching and learning is a fundamental aspect of } \\
\text { effective teaching. This research, therefore, aims at examining } \\
\text { potential benefits of planning teaching and learning activities as } \\
\text { perceived by diverse group of school teachers. By using } \\
\text { descriptive-cum-survey design, } 397 \text { teachers were selected as a }\end{array}$ \\
\hline $\begin{array}{l}\text { Keywords: } \\
\text { Content Delivery, } \\
\text { Leaning, Outcomes, } \\
\text { Planning Teaching } \\
\text { and Learning, } \\
\text { Potential Benefits, } \\
\text { School Teachers' } \\
\text { Perspectives }\end{array}$ & $\begin{array}{l}\text { sample trom } 43 \text { schools of two districts, by employ } \\
\text { multistage cluster technique. A self-designed questionn } \\
\text { comprising 18-sattements was used as tool for collection of } \\
\text { on five-point scale. The data were analyzed using descript } \\
\text { cum -inferential statistics. This research found that ove } \\
\text { teachers believe that planning of teaching and learning activi } \\
\text { is highly helpful in delivery of content; in achieving stude }\end{array}$ \\
\hline $\begin{array}{l}\text { *Corresponding } \\
\text { Author }\end{array}$ & $\begin{array}{l}\text { arning outcomes; managing and organizing students' learning } \\
\text { tivities, resources; and for enhancing quality of teaching. It } \\
\text { as further concluded that teachers don't' differ in their beliefs } \\
\text { their positions and all are of the same view that planning of } \\
\text { aching and learning activities is highly helpful in delivery of } \\
\text { ntent; achieving students' learning outcomes; managing and } \\
\text { ganizing students' learning activities, resources; and for } \\
\text { hancing quality of teaching. }\end{array}$ \\
\hline
\end{tabular}

\section{Introduction}

Planning plays very significant role in achieving goals. Especially in teaching, planning is vital because it gives teachers a concrete direction of what they want to do in a day (Serdyukov \& Ryan, 2008). Likewise, Straessle (2014) also mentioned that planning plays a substantial role in teaching and learning within classroom; that teachers plan in rich variety of ways which have a real outcome in classroom; that 
instructors' theories and the system of beliefs influence their plans and the actions; and that teachers make frequently plans during interactive teaching.

\section{Literature Review}

Planning generally includes various directions, potential decisions and actions to be performed. For instance, Gallego (2007) asserted that planning unites some decisions about the sequencing of each didactic unit. Likewise, Cicek (2014) believes that planning is a systematic process of making decision on what and how the learners should learn. Planning is also identified as the representation of an organization of teaching and learning process (Louws, Meirink, van Veen, \& van Driel, 2017; Luo, Murray, \& Crompton, 2017). As the lesson or didactic is considered as the basic unit of organizing the pedagogic actions, planning therefore implies the design and organization of learning sphere and it can be described as the sum of organized and sequence of didactics units (Gallego, 2007; Luo, Murray, \& Crompton, 2017).

Planning of teaching and learning is a complex process (Sahin-Taskin, 2017). Lesson plan is a systematic record of instructors' thoughts about what will be covered during a lesson (Farrell, 2002; Ramdiah, Abidinsyah, Royani, \& Husamah, 2019). Milkova (2012) argued that planning of lessons is the teacher's road map of what pupils need to learn and how it will be efficient achieved during the class time. An effective planning of teaching and learning addresses and integrates three key components. These include objectives or students' learning outcomes, the planning of teaching and learning activities and strategies to assess students understanding and their learning outcomes (Louws et al., 2017; Reynolds, \& Kearns, 2017; Thurlings, \& den Brok, 2017). Likewise, Serdyukov and Ryan (2008) described lesson plan as a plan which guide the teachers for running the particular lesson, and it also includes the goals (what the leaner are supposed to obtain), how these goals will be achieved (the method, the procedure) and the way of measuring how well these goals were reached (test, homework, the worksheets etcetera).

Lesson planning is the core of the teaching. It permits teachers to create an orientation path in teaching process by taking into account students' learning styles, their background knowledge, intelligences types, aptitude, and their interests (Gunawan, 2018; Milkova, 2012; Reynolds, \& Kearns, 2017). Effective plans are accentuated by the principles of the coherence, the flexibility and integration of knowledge (Lika, 2017; Luo et al., 2017).Lesson planning is also essential for effective teaching and to attain learning outcomes. Several research scholars highlight that lesson plans are greatly appreciated for providing an effective learning environment (Moonsri,\& Pattanajak, 2013; Johnson, 2000; Rusznyak,\& Walton, 2011). Serdyukov and Ryan (2008) also argued that planning lesson is also essential because it assists teachers to ensure that daily activities which go on in classrooms are providing learners with an adequate level of long-term achievement toward outlined goals in their scope and sequence, also their individual education plan when required. 
Lesson plans support pre-service educators to fill the gap between theory and the practice (Fujii, 2019; Sahin-Taskin, 2017).

Lesson plans are also important because of internal and the external reason (Morris, \& Hiebert, 2017; Sahin-Taskin, 2017; Tsui, 2003). The external drivers behind planning of lessons are that teachers plantheir teaching in order to meet the expectations of the principal or supervisor and to assist substitute teacher just in case the class needs one. Likewise, planning of teaching and learning is exclusively important for prospective teachers as they may feel more confident to be in control before the lesson begins. The internal reasons are that the teachers plan the lesson in order to become more confident, have better understanding of the subject matter, to enable themselves to deliver lessons smoothly and to tackle problems before they occur in classrooms (Farrell, 2002). An effective lesson plan does not have to be an exhaustive document which describes each and every possible classroom state. Instead, it should provide a general outline of the teaching goals, the learning objectives and the means to achieve them. Lesson plan is the reminder of what to do and how you want to do it (Milkova, 2012; Morris, \& Hiebert, 2017).

Many scholars identified the potential benefits of planning of teaching and learning for students and teachers (Farrell, 2002. Luo et. al., 2017; Ramdiah et al., 2019). These include the benefits in delivery of content; achieving students' learning outcomes; time management, organization management of activities and resources; enhancing quality of teaching and students' learning, and classroom assessment/evaluation. Fromperspective of teaching, Straessle (2014) asserted that an effective teacher is an effective planner as it would be difficult to deliver an effective instruction without having a concrete solid plan beforehand. These lesson plan would be based on teachers' knowledge about their pupils, the subject matter, resources, and available teaching strategies. Jensen (2001) believes that lesson planning creates more unified lessons. Moreover, lesson planning gives the teachers a chance to think purposely about their selection of lesson objectives, the types of cocurricular and curricular activities to attain those objectives, the sequence of activities, the required materials, how much time allocated to each activity, and how students should be grouped (Cicek \& Tok, 2014; Jensen, 2001; Landin, 2019). Likewise, Vdovina and Gaibisso (2013) argued that lesson plan assist tutors to have a proper framework for carrying their students to specific learning outcomes. Similarly, Jones (2018) asserted that lesson planning can assists tutors to be well prepared and comprehend what they intend to do while teaching their students.

Planning teaching and learning in advance not only affects teachers' instructions but also likely to affect classroom management. For example, Wong (2009) argued that the characteristics of a planned and a well-managed classroom are that learners should know what is expected from them; likelihood of implementing the good lesson plans; work-oriented, relaxed and pleasant climate; and learningoriented classrooms. This would be possible by good time management, by effective implementation of good lesson plans; by deeply engaging learners with their work; by describing clearly the roles of students, by writing good lesson plans; wise use of 
time, avoid confusion; and finally by an effective implementation of lesson planning (Jensen, 2001; Jones, 2018; Landin, 2019; Wong, 2009).

Effective planning of teaching and learning helps teachers to execute their instruction well to achieve students' learning outcomes. Jones (2018) asserted that well-organized teacher always have an ability to deliver the lesson within the given framework. By saving this additional time, a well-organized teacher can give an additional time and the attention to learners which demands an additional help. Panasuk, Stone and Todd (2002) argued that planning of teaching includes a conscious effort by the instructors to develop the coherent system of actions which promotes the development of pupils' cognitive structures. Planning of teaching is an essential aspect of teachers' job which directly impacts what and how students learn essential materials (Straessle, 2014). Planning lessons also assists instructors to assess their teaching and to compare it with the set objectives. Such assessment would help teachers in realizing the extent to which those set targets and goals have been achieved (Jones, 2018; Ramdiah et. al., 2019).

In summary, planning of teaching, learning is an essential component of teaching. It is evident from literature that an effective planning of teaching and learning activities helps in delivery of content; in achieving students' learning outcomes; managing and organizing time, resources, and learning activities; and for enhancing quality of teaching (Cicek \& Tok, 2014; Gunawan, 2018;Landin, 2019; Reynolds, \& Kearns, 2017). Despite the significance of planning teaching and learning, the personal experiences of researchers and conversations with school teachers suggests that some school teachers consider it a routine activity, with no potential benefits. This research, therefore, aims at examining the potential benefits of planning teaching and learning activities as perceived by diverse group of school teachers. Specifically, this study will examine potential benefits of planning teaching and learning, if any, in delivery of content; in achieving students' learning outcomes; managing and organizing time, resources, and learning activities; and in enhancing the quality of teaching and learning. This research will further examine the differences among teachers by their positions about the potential benefits and the advantages of planning teaching and learning activities in classrooms, as perceived by teachers of school.

\section{Hypotheses}

The following hypothesis was stated to examine the differences among school teachers by their positions about potential benefits and advantages of planning teaching and learning activities in classrooms, as perceived by them:

$\mathrm{H}_{1}$ : Teachers in schools significantly differ by their positions about potential benefits and advantages of planning teaching and learning activities in classrooms, as perceived by them. 


\section{Material and Methods}

\section{Design and Respondents}

This research employed descriptive-cum-survey design. Delimited to the school teachers from two districts of Southern Punjab (i.e., Multan \& Khanewal), all teachers served as an accessible population. For selection of sample, multistage cluster sampling was employed. Firstly, forty-three(43) schools were randomly selected from the two districts. The district Multan being as a larger and the Khanewal as smaller district, 22 schools were selected from the former and 21 from the later one. Secondly, all teachers from these 43 schools were taken as a sample. After seeking consent from 593 teachers of 43 schools, research tool was distributed to all teachers. Of 593 teachers with consent from 43 schools, 397responded back to the tool, with a response rate of $67 \%$. Consequently, these 397 teachers from 43 schools of two districts were taken as a sample. Of these 397 teachers, 122 were PSTs (Primary School Teachers), 136were the ESTs (Elementary School Teachers), and 139 were SSTs (Secondary School Teachers).

\section{Research Instrument}

Based on literature in the area of planning teaching and learning, a questionnaire was designed by researchers for examining the potential benefits and advantages of planning teaching and learning activities. Followed by seeking respondents' demographic information, questionnaire comprised 18 statements related to the potential benefits of planning teaching and learning. Of these 18 statements, four were related to benefits of planning of teaching and learning activities in delivery of content, four were related to the benefits of planning of teaching and learning in achieving students' learning outcomes, five were related to examining the role of planning in managing and organizing time, resources and learning activities, and five were related to role planning of teaching and learning activities in enhancing the quality of teaching and learning. The research instrument was found to be highly reliable with Cronbach reliability coefficient ( $r$ ) value of 0.93.Likewise, the validity of questionnaire was confirmed through literature and by the experts' opinions. Furthermore, questionnaire was designed on five-point Likert scale.

\section{Results and Discussion}

Aligned with research questions, both descriptive and inferential statistics (standard deviation, mean, and independent sample t-test) were employed, as interpreted below.

\section{Perceived Benefits of Planning Teaching and Learning}

Table 1 presents results about potential benefits of planning teaching and learning activities in delivery of content, based on values of SD and mean. 
Table 1

Benefits - Delivery of content as perceived by teachers

\begin{tabular}{clcc}
\hline No & \multicolumn{1}{c}{ Delivery of content } & Mean & SD \\
\hline 1 & $\begin{array}{l}\text { Planning teaching provides direction towards learning } \\
\text { goals. }\end{array}$ & 3.89 & 0.89 \\
\hline 2 & $\begin{array}{l}\text { Planning teaching provides framework for delivery of } \\
\text { lesson. }\end{array}$ & 3.82 & 0.84 \\
\hline 3 & $\begin{array}{l}\text { Planning teaching helps in effective communication of } \\
\text { content. }\end{array}$ & 4.14 & 0.98 \\
\hline 4 & $\begin{array}{l}\text { Planning teaching provides helps in evaluation of } \\
\text { teaching. }\end{array}$ & 3.42 & 1.24 \\
\hline 5 & Overall & 3.82 & 0.99 \\
\hline
\end{tabular}

Mean value of one statement in Table1is 3.42, which shows that teachers believe that planning of teaching slightly helps in evaluation of teaching. The mean values of other three statements are around 4, which reveal that school teachers believe that planning of teaching and learning provides direction towards learning goals, provides framework for delivery of lesson, and helps in effective communication of content. Overall mean of 3.82 also reflects that teachers highly agreed about potential benefits of teaching and learning activities in delivery of content. The SD of 0.99 indicates that teachers have good level of agreement about higher potential benefits of planning teaching and learning in the delivery of content. Table 2 presents analysis of data about benefits of planning teaching and learning regarding students' learning outcomes.

\section{Table 2}

Benefits - Students' learning outcomes

\begin{tabular}{clcc}
\hline S. No. & \multicolumn{1}{c}{ Students' learning outcomes } & Mean & SD \\
\hline 1 & $\begin{array}{l}\text { Planning teaching - A tool for achieving of learning } \\
\text { outcomes. }\end{array}$ & 3.91 & 1.08 \\
\hline 2 & $\begin{array}{l}\text { Planning teaching - Enriching students' learning } \\
\text { experiences. }\end{array}$ & 4.13 & 0.96 \\
\hline 3 & $\begin{array}{l}\text { Planning teaching - Enhancing students' learning } \\
\text { experiences. }\end{array}$ & 3.06 & 1.35 \\
\hline 4 & Planning teaching - A tool for assessing learning outcomes. & 4.01 & 0.98 \\
\hline 12 & Overall & 3.78 & 1.09 \\
\hline
\end{tabular}

Mean value of one statement in Table 2 is 3.06, which shows that teachers believe that planning of teaching slightly helps in enhancing students' learning experiences. The mean values of other three statements are just around 4, which reveal that school teachers believe that planning of teaching and learning acts as a tool for achieving students' learning outcomes, for enriching students' learning experiences, and for assessing students' learning outcomes. Overall mean of 3.78 also reflects that teachers highly agreed about potential benefits of teaching and learning activities in students' learning outcomes. The SD of 1.99 indicates that teachers have good level of agreement about higher potential benefits of planning teaching and 
learning in ensuring and enhancing students' learning outcomes. Table 3 presents analysis of data about the benefits of planning teaching and learning in managing and organizing classroom activities and resources.

Table 3

Benefits - Managing and organizing activities and resources

\begin{tabular}{cllcc}
\hline S. No. & \multicolumn{1}{c}{ Managing activities, time, and resources } & Mean & SD \\
\hline 1 & Planning teaching - Helps in organizing learning activities. & 4.12 & 0.91 \\
\hline 2 & $\begin{array}{l}\text { Planning teaching - Helps in engaging students with } \\
\text { learning. }\end{array}$ & 3.95 & 1.16 \\
\hline 3 & $\begin{array}{l}\text { Planning teaching - Helps in managing classroom } \\
\text { resources. }\end{array}$ & 3.98 & 0.92 \\
\hline 4 & $\begin{array}{l}\text { Planning teaching - Helps in effective management of } \\
\text { time. }\end{array}$ & $\begin{array}{l}4.07 \\
\text { Planning teaching - Provides bases for classroom } \\
\text { management. }\end{array}$ & 3.76 & 0.76 \\
\hline 12 & Overall & 3.98 & 0.96 \\
\hline
\end{tabular}

Mean value of one statement in Table 3 is 3.76, which shows that teachers believe that planning of teaching provides bases for classroom management to a very good extent. The mean values of the remaining four statements are around or greater than 4, which reveals that school teachers believe that planning of teaching and learning extremely helps in organizing learning activities; helps in engaging students with learning; helps in managing classroom resources; and helps in effective management of time. Overall mean of 3.98 also reflects that teachers highly agreed about potential benefits of teaching and learning activities in in managing activities, time, and resources. The SD of 0.96 indicates that teachers have higher level of agreement about higher potential benefits of planning teaching and learning in managing classroom activities, time, and resources. Table 4 presents analysis of data about the benefits of planning teaching and learning in enhancing the quality of teaching.

Table 4

Benefits - Enhancing the quality of teaching

\begin{tabular}{|c|c|c|c|}
\hline S. No. & Enhancing quality of teaching & Mean & SD \\
\hline 1 & $\begin{array}{l}\text { Planning teaching - Adopt techniques aligned with } \\
\text { content. }\end{array}$ & 4.00 & 1.15 \\
\hline 2 & Planning teaching - Adapt teaching aligned with content. & 3.89 & 1.05 \\
\hline 3 & $\begin{array}{l}\text { Planning teaching - Leads to improvement of teaching } \\
\text { skills. }\end{array}$ & 3.77 & 1.13 \\
\hline 4 & Planning teaching - Enhances effectiveness of teaching. & 3.98 & 1.00 \\
\hline 5 & Planning teaching - Improves overall quality of teaching. & 3.44 & 1.62 \\
\hline 12 & Overall & 3.82 & 1.19 \\
\hline
\end{tabular}

Mean value of one statement in Table 3 is 3.44, which shows that teachers believe that planning of teaching provides bases for classroom management to the moderate extent. The mean values of the remaining four statements are around or below than 4 , which reveals that school teachers believe that planning of teaching 
and learning helps teachers in adopting and adapting teaching techniques in alignment with content, helps in improving teaching skills of students, and helps in enhancing effectiveness of teaching. Overall mean of 3.82 also reflects that teachers highly agreed about potential benefits of teaching and learning activities in enhancing overall quality of teaching. The SD of 1.19 show that teachers have moderate level of agreement about higher potential benefits of planning teaching and learning in the quality of teaching. Figure 1 presents visual picture of analysis of data about benefits of planning teaching and learning in four areas, such as the role of planning in delivery of content; in achieving students' learning outcomes; in managing/organizing students' learning activities, resources; and time; and in enhancing the quality of teaching.

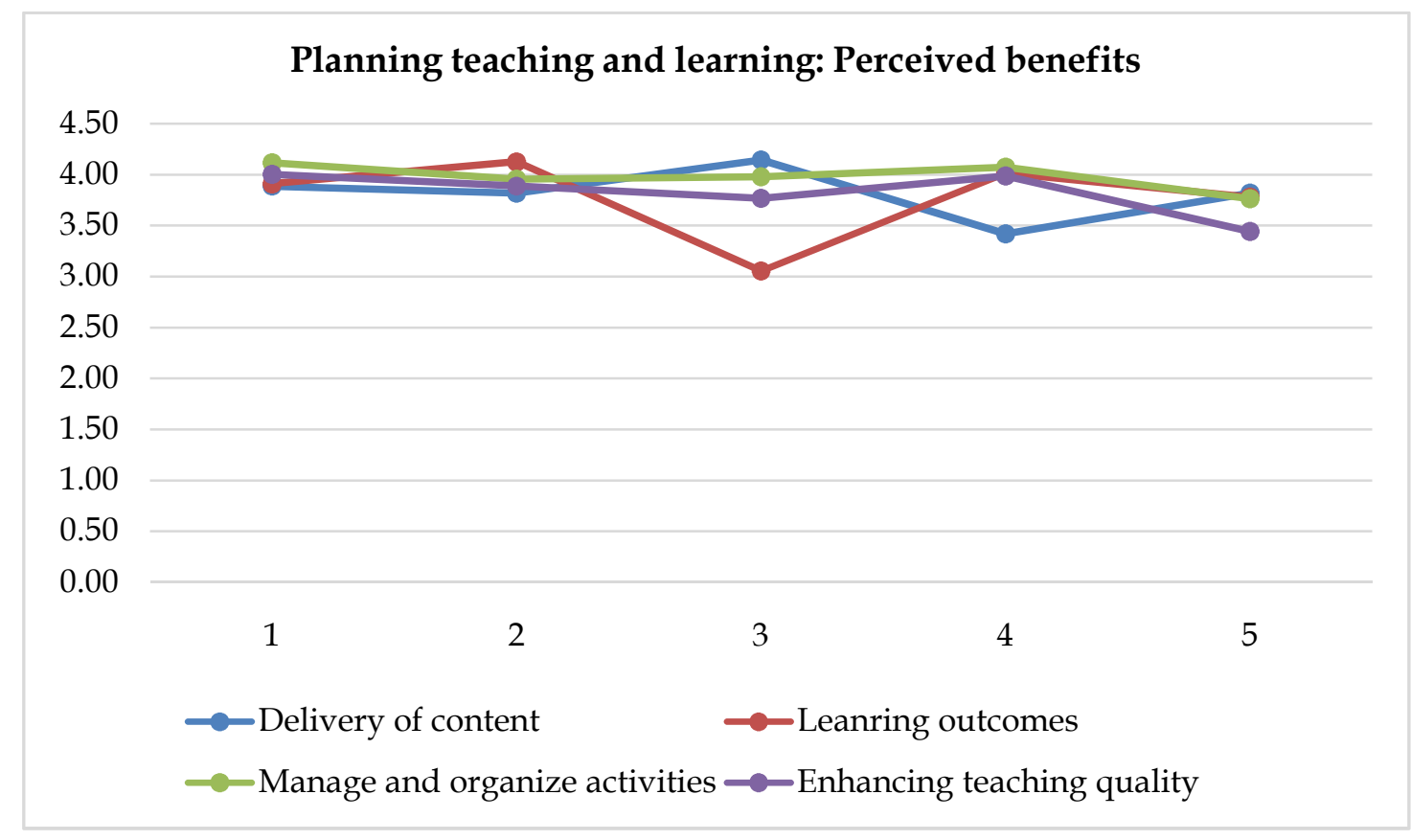

Figure 1: Potential benefits of planning teaching and learning

Figure 1 shows that school teachers believe that planning of teaching and learning activities are very highly beneficial in managing and organizing students' learning activities, resources, and time management (Mean $=3.98)$, followed by its benefits in delivery of content (Mean $=3.82$ ); in enhancing quality of teaching (Mean = 3.82); and high impact of lesson planning in achieving students' learning outcomes (Mean $=3.78)$. Overall, teachers believe that planning of teaching and learning activities is highly helpful in delivery of content; in achieving students' learning outcomes; managing and organizing students' learning activities, resources; and for enhancing quality of teaching. Table 5 presents analysis of data for examining the differences among teachers by their positions about perceived benefits of planning teaching, by applying ANOVA. 
Table 5

Differences among teachers by their positions (ANOVA)

\begin{tabular}{ccccccc}
\hline Positions of teachers & N & Mean & df & F & Sig. \\
\cline { 1 - 3 } PSTs & 122 & 68.1639 & & & \\
ESTs & 136 & 70.4412 & & 394 & .556 & .574 \\
\cline { 1 - 3 } SSTs & 139 & 69.2806 & & & \\
\hline Total & 397 & 69.3350 & & 396 & & \\
\hline
\end{tabular}

Table 5 indicates that the mean values for all three categories of teachers by their positions are different. The Sig. value of .574 is, however, greater than .05 . It shows that differences in mean values are not significant. It can be thus concluded that teachers don' $t$ ' differ in their beliefs by their positions and all are of the same view that planning of teaching and learning activities is highly helpful in delivery of content; in achieving students' learning outcomes; managing and organizing students' learning activities, resources; and for enhancing quality of teaching. The research hypothesis was rejected and null was accepted.

\section{Discussion}

This research observed that teachers highly agreed about potential benefits of planning teaching and learning activities in delivery of content. In consistent with views of the scholars, teachers believe lesson planning gives the teachers a chance to think purposely about their selection of lesson objectives, the types of co-curricular and curricular activities to attain those objectives, the sequence of activities, the required materials, how much time allocated to each activity, and how students should be grouped (Cicek \& Tok, 2014; Gunawan, 2018; Jensen, 2001; Landin, 2019; Reynolds, \& Kearns, 2017). This research also found that teachers highly agreed about potential benefits of teaching and learning activities in students' learning outcomes. This result is also consistent with researchers who believe that planning helps in designing objectives or students' learning outcomes, planning of teaching and learning activities and plans to assess students understanding and their learning outcomes (Louws et al., 2017; Reynolds, \& Kearns, 2017; Thurlings, \& den Brok, 2017).Several research scholars highlight that lesson plans are greatly appreciated for providing an effective learning environment (Moonsri,\& Pattanajak, 2013; Johnson, 2000; Rusznyak,\& Walton, 2011).

This study revealed that teachers highly agreed about potential benefits of teaching and learning activities in in managing activities, time, and resources.This finding is in alignment with views of other scholars, who believe that lesson planning greatly helps teachers in the organization of teaching and learning process (Louws, Meirink, van Veen, \& van Driel, 2017; Luo, Murray, \& Crompton, 2017).This study revealed that teachers highly agreed about potential benefits of teaching and learning activities in enhancing overall quality of teaching. Straessle (2014) also mentioned that planning plays a substantial role in teaching and learning within classroom; that teachers plan in rich variety of ways which have a real outcomes in classroom; that instructors' theories and the system of beliefs influence their plans 
and the actions; and that teachers make frequently plans during interactive teaching. Such assessment would help teachers in realizing the extent to which those set targets and goals have been achieved (Jones, 2018; Ramdiah et. al., 2019). All these results shows that although teachers perceive that potential benefits of the planning of teaching are significant both for teaching and students' learning, but most of these benefits are underutilized by teachers and leaders in schools.

\section{Conclusions and Recommendations}

A number of conclusions drawn from this research led to few recommendations. Both conclusions and recommendations are being made here. First, this research concluded that teachers highly agreed about potential benefits of lesson planning in delivery of content. Based on these results, it is therefore recommended for school heads to ensure that teachers at their schools plan their lessons on continuous basis to earn its potential benefits. Second, this research concluded that teachers highly agreed about potential benefits of teaching and learning activities in students' learning outcomes. The main purpose of teaching is also to achieve students' learning outcomes and it may be thus suggested to link the planning phase of teaching and learning with achieving students' learning outcomes. Third, it is concluded that teachers highly agreed about potential benefits of teaching and learning activities in in managing activities, time, and resources. It is therefore suggested for teachers and heads to document all these activities to ensure students' learning. Fourth, this research concluded that teachers highly agreed about potential benefits of teaching and learning activities in enhancing overall quality of teaching. Based in this, it is, therefore, suggested for professional development staff to arrange their programs in such a way that they put focus on training of their teachers in this important domain of teaching. 


\section{References}

Cicek, V., \& Tok, H. (2014). Effective use of lesson plans to enhance education in US and Turkish kindergarten thru 12th grade public school system: A comparative study. International Journal of Teaching and Education, 2(2), 10-20.

Farrell, T. S. (2002). Lesson planning. Methodology in language teaching: An anthology of current practice, 11(2), 30-39.

Fujii, T. (2019). Designing and adapting tasks in lesson planning: A critical process of lesson study. In Theory and practice of lesson study in mathematics (pp. 681704). Springer, Cham.

Gallego, M. R. R. (2007). Lesson planning in primary and secondary education. Research Gate, https://www.researchgate.net/publication/269463679_Lesson_planning_in_Pri mary_and_Secondary_Education.

Gunawan, I. (2018). The implementation of lesson study based learning management and the effect toward students' activeness in lecturing. Jurnal Pendidikan dan Pembelajaran, 24(2), 51-63.

Johnson, A. P. (2000). It's time for Madeline Hunter to go: A new look at lesson plan design. Action in teacher education, 22(1), 72-78.

Jones, S. (2018). 3 Reasons why it is important to plan lessons. The e-learning network, https://www.eln.io/blog/3-reasons-lesson-planning

Jensen, L. (2001). Planning lessons. in Teaching English as a second or foreign language, Heinle \& Heinle

Landin, J. M. (2019). Excellence in lesson planning: The purpose and use of a microuniting template. Journal of Higher Education Theory \& Practice, 19(5), 91-97.

Lika, M. (2017). The impact of curricula and lesson planning in the teaching process. Academic Journal of Business, Administration, Law, and Social Science, 3(1), 240-247.

Louws, M. L., Meirink, J. A., van Veen, K., \& van Driel, J. H. (2017). Teachers' selfdirected learning and teaching experience: What, how, and why teachers want to learn. Teaching and teacher education, 66(1), 171-183.

Luo, T., Murray, A., \& Crompton, H. (2017). Designing authentic learning activities to train pre-service teachers about teaching Online. International Review of Research in open and distributed Learning, 18(7), 141-156.

Milkova, S. (2012). Strategies for effective lesson planning. Center for Research on learning and Teaching, 1-4. 
Moonsri, A., \& Pattanajak, A. (2013). Lesson planning in primary school using lesson study and open approach. Psychology, 4(12), 1064-1077.

Morris, A. K., \& Hiebert, J. (2017). Effects of teacher preparation courses: Do graduates use what they learned to plan mathematics lessons? American Educational Research Journal, 54(3), 524-567.

Panasuk, R. M., \& Todd, J. (2005). Effectiveness of lesson planning: Factor analysis. Journal of Instructional Psychology, 32(2). 215-232

Ramdiah, S., Abidinsyah, A., Royani, M., \& Husamah, H. (2019). Understanding, planning, and implementation of HOTS by senior high school biology teachers in Banjarmasin-Indonesia. International Journal of Instruction, 12(1), 425-440.

Reynolds, H. L., \& Kearns, K. D. (2017). A planning tool for incorporating backward design, active learning, and authentic assessment in the college classroom. College Teaching, 65(1), 17-27.

Rusznyak, L., \& Walton, E. (2011). Lesson planning guidelines for student teachers: A scaffold for the development of pedagogical content knowledge. Education as change, 15(2), 271-285.

Sahin-Taskin, C. (2017). Exploring Pre-Service Teachers' Perceptions of Lesson Planning in Primary Education. Journal of education and practice, 8(12), 57-63.

Serdyukov, P., \& Ryan, M. (2008). Writing effective lesson plans: The 5-star approach. Pearson Allyn and Bacon.

Straessle, Jessica Miller Wunderle. (2014). Teachers' perspectives of effective lesson planning: A comparative analysis. Dissertations, Theses, and Masters Projects. Paper 1550154173.https:/ / dx.doi.org/doi:10.25774/w4-8swa-7371

Thurlings, M., \& den Brok, P. (2017). Learning outcomes of teacher professional development activities: a meta-study. Educational review, 69(5), 554-576.

Tsui, A. (2003). Understanding expertise in teaching: Case studies of second language teachers. Cambridge University Press.

Vdovina, E., \& Gaibisso, L. C. (2013). Developing critical thinking in the English language classroom: A lesson plan. ELTA journal, 1(1), 54-68.

Wong, H. K., \& Wong, R. T. (2009). The first days of school: How to be an effective teacher. Harry K. Wong Publications, 12(1), 81-87. 